\title{
Impact Of Using Joint Productive Activity Approach On Second Language Learners' Performance In Reading Comprehension At The Basic Education Level In Nigeria
}

\author{
HANNA ONYI YUSUF \\ Department of Educational Foundation and Curriculum \\ Faculty of Education \\ Ahmadu Bello University, Samaru-Zaria, Nigeria \\ E-mail:hannayusuf@yahoo.com
}

Doi:10.7575/aiac.alls.v.4n.1p.51

Received: 02/12/2012

URL: http://dx.doi.org/10.7575/aiac.alls.v.4n.1p.51

Accepted: 03/01/2013

\begin{abstract}
This study investigated the impact of using joint productive activity on the performance of second language learners in reading comprehension at the basic education level in Nigeria. A sample of forty (40) Junior Secondary II students from Kaduna North and South were used for the study. The study was quasi experimental. Government Junior Secondary School Doka was used as the experimental group while Government Junior Secondary School Makera was used as the control group. Both groups were assessed after six weeks of teaching using two reading comprehension tests. T-test was used to test the hypothesis raised in the study. The findings revealed significant differences in the performance of students taught reading comprehension using joint productive activity. Based on the findings teachers are encouraged to use joint productive activities in teaching reading comprehension. This is a positive deviation from the traditional practice in Nigeria where a teacher is regarded as the sole custodian of knowledge and students are empty tabula rasa who should be passive during class teaching. Teachers need to exploit this new approach by designing teaching comprehension activities that will require second language learners' collaboration and active participation in accomplishing tasks jointly in class with the teacher.
\end{abstract}

Keywords: Productive activity, SLA, Reading

\section{Introduction/Background to the study}

Studies such as (Oyetunde 2009, Olaofe 2013, Yusuf 2005, 2011, 2013) have attributed students' poor performance in reading, to lack of appropriate methods of teaching reading, among other factors. Alvermanu, Dillon and O' Brien (1987) Umolu and Oyetunde (1991) and Odumuh (1997) have equally asserted that the inability of students graduating from most Nigerian secondary schools unable to read in English have assumed such alarming proportion in the past decade that a study such as this becomes necessary.

In today's complex society, reading is a critical skill for children's success both in and out of school. In the school setting, children are expected to read textbooks. Assignments are given to them on the assumption that they can obtain information from the printed page independently. Outside of school children still need good reading ability to cope with the challenges of their everyday living.

In view of all of the above, any effort made towards ensuring that children develop efficient reading skills is neither wasted nor misplaced. As a matter of fact, if children develop good reading skills and a love for reading, they have a key tool, which will help them continue learning and growing.

As learning to read is a continuous process, the conditions of instruction at the basic education level significantly affect the extent to which the learner will eventually attain the required level of literacy. It is at the basic education level that students are expected to develop some basic reading skills. This, however, is often not the case for second language learners in Nigeria. Most pupils, especially those about to enter JSS one, are deficient in basic reading skills. Some of them cannot even read a word of English at primary six, and there is ample evidence that a high proportion of pupils are at a stage when they need further developmental reading instruction. Unfortunately, at this level which is supposed to be the bedrock of all subsequent levels of education, there is no reading instruction, except for 'comprehension lessons' in their English classes which as Oyetunde (2009), and Olaofe (2013) observe serve as a test of reading comprehension rather than reading instruction. Teachers at this basic foundation level unfortunately lack training in reading and reading instruction, (Umolu and Oyetunde 1991).

Reading is largely taken for granted particularly at tertiary school level, and language teachers hardly think of it as a basic skill that requires the most careful attention. Yet if a child fails to master the skills of reading, the rest of the education is either a flat failure or only a limping success. Research figures are hardly needed to demonstrate that most primary and secondary school students in Nigeria cannot read with adequate comprehension. These inadequacies are clear in their inability to cope with the texts provided for them; they indicate their limitations by their failures in the final written examinations. Moreover, many of them are unable to read and therefore, cannot understand and complete application forms for further studies. In view of the absolutely indispensable role of reading in modern life and the fact 
that a civilized standard of living is not attainable without the ability to read, the need to undertake this study cannot be denied.

\section{Review of Related Literature}

Studies in the first language (Devine, 1981, Carroll, 1972) regarding the influence of different factors on reading achievement and comprehension have revealed that the situation is not same in the second language situation. Factors, which have been found to be significant in the first language situation, may not necessarily account for reading difficulties in a second language situation. For instance, many studies in the first language have emphasized the importance of home background, family size and parental concern for their children's progress in school (Thorndike, 1973).

In a second language situation (such as teaching English in Nigeria), there are additional factors such as cultural factors, which impede the learners' reading achievement. Olaofe (2013) identifies the reading problems of secondary school students as slow, poor comprehension, poor recall, inadequate vocabulary, and inadequate reading interest. Crosscultural studies which have tried to compare the performance of Nigerian Students with that of their counterparts in developed countries depict a gloomy picture (Oyetunde 2009, Olaofe 2013).

The influence of some of the factors may be greater in real terms today, given the condition of educational institutions in today's Nigeria. These factors include, according to Odumuh (1997), lack of qualified teachers, poor classroom condition, lack of adequate materials, large class size and little or no encouragement from parents, home, teacher and peer group.

Most studies in reading comprehension so far conducted in Nigeria have concentrated on examining reading difficulty of students at the primary and junior secondary levels with focus on the texts being used. However, there are reasonable grounds to suspects that other non-text factors, such as pedagogical factors, affect reading comprehension as well. Literature search reveals that pedagogical factors have received little or no attention in Nigeria (Oyetunde 2009, Olaofe 2013). The absence of such crucial information constitutes a problem which has motivated the present study. The study is also based on the premise that the comprehension of a textbook depends on the interaction of a number of factors, which can be broadly categorized into four: socio-cultural, linguistic, psychological and pedagogical factors. The influence of these factors on the reader's comprehension especially in a second language situation is uncertain. There is, therefore, the need to ascertain the extent to which pedagogical factors influence reading comprehension.

Doherty and Pinal (2002) and Tharp (2002) used standard performance to examine the influence of teachers' use of joint productive activity (JPA) during language arts instruction on the metacognitive development of predominantly Latino English language learners (ELL) during class instruction, the teacher and a small group of students co-construct meaning from a text. The teacher is a full collaborator in the activity, modelling the use of effective reading comprehension strategies while assessment and assisting students' comprehension efforts. This study found the use of cognitive reading strategies through teacher's use of JPA facilitated students' comprehension. JPA was unrelated to self-report of ineffective achievement gains on standardized comprehension achievement.

The focus of this study, therefore, is to determine the impact of joint productive activity method on the performance of second language learners in reading comprehension at the basic education level in Nigeria. The basic education is the bedrock upon which the secondary and tertiary levels are dependent. If this foundation level is faulty, students are bound to have difficulty in comprehending texts at the secondary school level and even beyond tertiary institutions. To this end this study will focus on one out of the five pedagogic methods of the centre for Research on Education Diversity and Excellence (CREDE) based in the United States of America i.e Joint Productive Activity (JPA). These pedagogic methods have proved successful over several decades across grade levels, student populations and content areas. Doherty \& Pinal 2002, Doherty, Hilberg, Epaloose \& Tharp 2002). This present sought to test one out of the five methods i.e Joint Productive Activity (JPA) to find out if it is likely to be effective in teaching reading comprehension to second language learners at the basic education level in Nigeria.

\subsection{Objective of the Study}

The objective of the study is to determine the impact of using joint productive activities on the performance of second language learners in reading comprehension at the basic education level in Nigeria.

\subsection{Research Question}

What is the impact of joint productive activity on the performance of second language learners in reading comprehension at the basic education level in Nigeria?

2.3 Hypothesis

Joint productive activity has no significant impact on the performance of second language learners in reading comprehension at the basic education level in Nigeria.

\section{Methodology}

The subject of the study were forty (40) students of Junior Secondary II from Government Junior Secondary School (GJSS) Doka in Kaduna North and Government Junior Secondary School (GJSS) Makera in Kaduna South. Twenty (20) students from each school. The two schools were located far apart to minimise interaction. The two teachers who taught the classes were judged to be comparable in teaching ability, on the basis of their equivalent qualification as Nigeria Certificate in Education (NCE) holders. Government Junior Secondary School, Doka was used as the experimental group while Government Junior Secondary School, Makera was used as the control school. The students in both schools were taught for six weeks.

Two reading comprehension tests were administered to the students. The reading comprehension tests were taken from the students' text titled Junior Secondary English Project Book 2. The comprehension questions were designed by the researcher so as to include literal questions, inferential questions and critical questions. 
3.1 Research Design

A quasi experimental non randomization control design was used. A pre-test post-test design was adopted. A pre-test was administered prior to the commencement of teaching (treatment) in order to establish the homogeneity of the students. A post-test was administered after six weeks of teaching to determine any probable changes in the experimental group. More questions were included in the post test since it was felt that by the end of the 6 weeks of teaching, the students would have been more familiar with the passage.

\subsection{Instrumentation}

The instruments used for the study were reading comprehension passages from which test items were drawn on joint productive activities critical thinking skills. Six passages were carefully selected from the Junior English Project for Junior Secondary Schools Book 2 text in use in the schools. The passages were selected because of its relevant subject matter and interest to both gender. The content of the passage was educative and informative and adequately provided some of the needed items for the tests.

\subsection{Administration of instruments}

A pre-test on two passages was administered to both control and experimental groups to establish the homogeneity of the students. The experimental group was taught reading comprehension using joint productive activities for six weeks while the control group had their normal reading comprehension lessons taught by their teacher.

A post-test (on the same two passages) was administered on the two groups after six weeks of teaching to determine the impact of joint productive activities on the performance of second language learners in reading comprehension. T-test was used to test for significant difference in the performance of students from both groups.

\subsection{Treatment}

\section{Joint Productive Activity method (JPA)}

The teacher:

i) facilitates learning through joint productive activities between teacher and students. For instance, in teaching reading comprehension, teacher elicits metacognitive activities by stimulating and guiding students in arriving at the right answers.

ii) designs instructional activities requiring student collaboration to accomplish a joint task. Such activities may include demonstration, dramatization, miming, songs and so on.

iii) matches the demands of the joint productive activity to the time available for accomplishing them;

iv) arranges classroom seating to accommodate students individual and group need to communicate work jointly;

v) participate with students in joint productive activity;

vi) organizes students in a variety of groupings, such as by friendship, mixed academic ability, language, project, or interest

to promote interaction;

vii) plans with students how to work in groups and move from one activity to another, such as from large group introduction to small group activity, for clean-up, dismissal, and the like; and

viii) manages student and teacher access to materials and technology to facilitate joint productive activity; and

$\mathrm{x}$ monitors and supports student collaboration in positive ways

\section{Analysis of Data}

Table 1. Presentation of test scores for the two groups for test N0 1 (Reading Comprehension Test 1)

\begin{tabular}{|l|l|l|l|l|}
\hline GROUP & TEST & N & Mean & SD \\
\hline \multirow{2}{*}{$\begin{array}{l}\text { Group I } \\
\text { Experimental method (JPA) }\end{array}$} & Pre-test 1 & 20 & 46.00 & 12.81 \\
\cline { 2 - 5 } $\begin{array}{l}\text { Group II } \\
\text { Control group }\end{array}$ & Pre-test 2 & 20 & 48.50 & 10.14 \\
\cline { 2 - 5 } & Pre-test 1 & 20 & 48.50 & 7.92 \\
\cline { 2 - 5 } & Pre-tes 2 & 20 & 45.00 & 10.72 \\
\hline
\end{tabular}

$\mathrm{P} \leq 0.05$

Table 2. Presentation of test scores for the two groups for test N0 2 (Comprehension Test 2)

\begin{tabular}{|l|l|l|l|l|}
\hline GROUP & TEST & N & Mean & SD \\
\hline $\begin{array}{l}\text { Group I } \\
\text { Experimental method (JPA) }\end{array}$ & Post-test 1 & 20 & 70.00 & 18.97 \\
\cline { 2 - 5 } & Post-test 2 & 20 & 68.50 & 15.58 \\
\hline Group II & Post-test 1 & 20 & 52.50 & 10.42 \\
\cline { 2 - 5 } Control (Traditional method) & Post-test 2 & 20 & 49.00 & 7.68 \\
\hline
\end{tabular}

$\mathrm{P} \leq 0.05$

Table 1 and 2 shows the performance of students in the pre-test and post-test for the experimental and control groups for test 1 and 2 .

To test the hypothesis which states that joint productive activity has no significant impact on the performance of second language learners in reading comprehension at the basic education level, the t-test was used. The summary of computations are shown in table 3 and 4. 
Table 3. comparison of pre-test and post-test scores for students in the Joint Productive Activity Approach (Experimental group)

\begin{tabular}{|l|l|l|l|l|l|l|l|}
\hline $\begin{array}{l}\text { GROUP 1 } \\
\text { Experimental group } \\
\text { JPA }\end{array}$ & TEST & mean & SD & DF & T-cal & T-Crit & Decision \\
\hline Test No. 1 & Pre-test & 46.00 & 12.81 & 38 & 4.69 & 1.960 & \\
& Post-test & 70.00 & 18.97 & & & & \\
\hline Test No. 2 & Pre-test & 48.50 & 10.14 & 38 & 4.81 & 1.960 & Rejected \\
& Post-test & 68.50 & 15.58 & & & & \\
\hline
\end{tabular}

$\mathrm{P} \leq 0.05$

From Table 3, the observed t-values were found to be significant at 0.05 . Hence, the null hypothesis which states that there is no significant impact of the joint productive activity approach on the performance of second language learners in reading comprehension is rejected and one could conclude that there was significant improvement on the performance of the second language comprehension using the Joint Productive Activity approach.

Table 4. comparison of pre-test and post-test scores for students in the traditional group (control group)

\begin{tabular}{|l|l|l|l|l|l|}
\hline GROUP 2 & TEST & X & SD & DF & T \\
Control Group & & & & & \\
\hline Test N0 1 & Pre-test & 48.50 & 7.92 & 38 & 2.350 \\
Reading comprehension & Post-test & 52.50 & 10.42 & & \\
\hline Test N0 2 & Pre-test & 45.00 & 10.72 & 38 & 2.360 \\
Reading Comprehension & Post-test & 49.00 & 7.68 & & \\
\hline
\end{tabular}

From table 4, the observed t-values were found not to be significant at 0.05 . Hence one can say that the traditional method has no significant impact on performance of second language learners in reading comprehension.

One can thus conclude that the JPA is relatively more effective in teaching second language learners reading comprehension. Since this group of students performed significantly better than those taught using the traditional method in the two reading comprehension tests. The post-test results, however, showed a general improvement as both groups performed better in the post-test than they did in the pre-test, which is probably as a result of instruction, since both groups were exposed to six weeks teaching.

\section{Discussion of Findings}

There is a general increase in the level of involvement and participation of the second language learners on the JPA in the experimental group probably because of the activities students were engaged in. Students and teachers were actively involved in the discussion of the passages before they were read. In the JPA lessons that were observed, second language learners generally showed keen interest in the discussion. Each student was eager to share his/her own experiences with the class. The students that were taught using the traditional method were not exposed to any Joint Productive tasks. Students' performances in the two (2) tests were generally low not because they lacked ability or because they are poor readers but probably because students were not involved actively in joint productive activity with their teacher. They were passive most of the time.

It is also interesting to note that the JPA group also performed better in the reading comprehension tests. Students performed very well in literal inferential and critical questions. Their scores were higher than those of the traditional group. This goes to confirm the studies of Doherty, Hilberg, Epaloose and Tharp (2002), Doherty and Pinal (2002), Mansur and Pantea (2012) which all point to the fact that the use of Joint Productive Activity Approach helps students to jointly select important information from the text and also encourages them to make use of their natural abilities to make and confirm predictions as they read and perform reading tasks jointly with their teachers. Teachers should therefore try as much as possible to design instructional activities that will require students' collaboration to accomplish tasks jointly with the teacher. Students stand to benefit a lot if they are actively engaged or involved in joint productive activities with their teachers.

\section{Conclusion}

Based on the empirical evidence presented, the JPA group has gained more than the conventional group. Thus the performance of second language learners in reading comprehension using joint productive activity approach was greatly enhanced and improved. This researcher therefore joins other researchers like Doherty and Pinal (2002), Doherty, Hilberg, Epaloose and Tharp (2002) in saying that the use of Joint Productive Activity is a positive deviation from the traditional practice where a teacher is regarded as the sole custodian of knowledge and students are merely regarded as empty "tabula rasa" or "clean slates" waiting to be written on. This approach needs to be exploited by all teachers. Students would definitely benefit more if teachers exploit this approach. Prospective researchers would surely benefit from this study by carrying out more investigations that would improve the teaching of reading comprehension using 
joint productive activity approach at the basic education level. This will go a long way to enhance and improve the performance of second language learners in English, since reading is one of the fundamental skills in language acquisition and learning and it is indispensable in academics and lifelong learning.

\subsection{Recommendations}

The following recommendations were made based on the findings of the study.

1. The school system in Nigeria should empower language and content areas teachers to be able to equip second language learners with the required attitude, knowledge, instructional practices and skills that will enable them meet the literacy demands of the $21^{\text {st }}$ century. The school system should expose second language learners to instructional practices that promote responsive interaction between teachers and learners such as JPA.

2. Teachers should be ready to implement joint productive activities by engaging all students in meaningful activities to facilitate second language learners' reading comprehension. These activities should be carried out jointly by teachers and learners in order to obtain meaningful results.

3. The use of JPA by teachers will change the role of the teacher in the classroom from that of a sole custodian of knowledge to a facilitator of learning by encouraging and helping learners to accomplish reading tasks jointly.

4. Teaching and learning should be student centred not teacher centred. There should be change or shift of focus from the teacher to the learners since the current trend in teaching is emphasising more of students' active participation rather than teacher centred orientation.

5. Teachers should always design instructional activities in reading comprehension that will require students' collaboration in accomplishing reading tasks jointly. Such activities should include dramatization, demonstration, miming, sketching and so on.

6. Teachers should always make sure in using joint productive approach that they organise second language learners in a variety of groupings such as mixed academic ability, reading ability, interest e.t.c to promote meaningful interaction.

7. Text book writers in English language for basic education should include joint productive activities as part of the exercises for reading comprehension.

8. Curriculum planners should include joint productive activities as part of the students' activities to be carried out in the reading component of the English language curriculum for basic education.

\section{References}

Alvermann, D. E., Dillon, D. R, and Brien, O. (1987) Using Discussion to Promote Reading Comprehension. Newark, Delaware: International Reading Association.

Carroll, J.B. (1972) "Defining Language, comprehension: some speculation" J. F. Carroll and R. O. Freele (Eds) Language comprehension and the acquisition of knowledge. Washington DC: Winston.

Devine, J. (1981). Developmental patterns in native and non-native reading acquisition. In S. Hudelson, (Ed.). Learning to Read in Different Languages, (Linguistics and Literacy Series 1). (ERIC Document Reproduction Services No.ED 198 744).

Doherty, R. W., \& Pinal, A. (2002). Joint productive activity and the development of metacognitive thinking. Manuscript submitted for publication.

Doherty, R. W., Hilberg, R. S., Epaloose, G., \& Tharp, R. G. (2002). Development of the standards performance continuum: A performance-based measure of the standard for effective pedagogy. Manuscript submitted for publication. Mansur, F and Pantea, H. (2012) "The effect of Critical Thinking on Developing Argumentative essays by Iranina EFL University students. Journal of language teaching and research, Vol 3 N0 4 pp 639-646, Finland: Academy Publisher July 2012.

Odumuh, T. O. (1997) Effect of motivation and prior knowledge on reading comprehension: A study of senior secondary school students in Gwagwalada area council of Federal Capital Territory unpublished Ph.D Dissertation, Faculty of Education A.B.U., Zaria.

Olaofe A.I (2013) "Teaching English in Second Language Adverse situations A Solution-based Approach". Zaria: Applied Linguistics and language Education Centre. Yahaya ventures.

Oyetunde T.O (2009). "Beginning Reading Scheme" Empowering teachers to help their pupils become good teachers. Jos: LECAPS publishers. Shertogenboch

Thorndike, R. L. (1973). Reading Comprehension Education in Fifteen Countries: An Empirical Study. Stockholm: International Association for the Evaluation of Educational Achievement (IEA).

Umolu J.J. and Timothy O. Oyetunde (1991) "Matching test with readers: Beyond readability formulas" Literary and Reading in Nigeria. 5:243-254.

Yusuf, H.O. (2005) "A comparative study of the effectiveness of language development and vocabulary methods in teaching reading comprehension" Unpublished Ph.D thesis, University of Abuja, Abuja.

Yusuf, H.O. (2011) "Towards Improvement in the teaching of reading comprehension in primary schools: the need to activate pupils' relevant schema". Theory and practice in language studies Vol 1 (1) January 2011. Pp 16-20 Academy Publishers.

Yusuf, H.O. (2013) "Infusing Entrepreneurial skills into the reading curriculum for basic education in Nigeria". International Journal of Humanities and Social Science California, State University, USA Vol 3 (3)) February 2013. 


\section{APPENDIX 1 \\ READING COMPREHENSION TEST 1}

Instruction: Read the passage below and answer the questions that follow

It was a sunny day in the month of May. The sun took its rightful position very early; lending credence to the general feeling that Andrew's birthday ceremony was going to be greeted with the blessing of pleasant weather. The sky looked so bright that Andrew insisted on having an open-air party. The habitual doubting Thomas had no dissenting opinions to express. Andrew had gone to great lengths to ensure a hitch-free party: a party which would remain the talk of the town. Although it was not intended to be free for all, a lot had been done to stamp the occasion on the memories of many people long afterwards.

The bright sun continued to smile: Andrew's face beamed with pleasure with every passing moment. Very few of his contemporaries have so succeeded in reaching the top of the ladder. Andrew in particular. Had been an orphan of storm. His father's death during his thirst year in the secondary school and that of his mother two year later were only two of this orphan storms. His suffered a physical misfortune when a stockfish machine severed his left middle finger. But Andrew did not despair.

The courage to fail is very cheap: Every fool can afford to fail. But it raises one above the head of cowards and neverdo-well to be up and struggling. The reward for forbearance in the end is resounding success. And so it was for Andrew. Ever since he finished his university education, it had been success galore. He had a got a good job in one of the country's insurance companies. His pay was good, his promotion had been steady and his prospects seemed bright. At forty, he had a good car and had already bought a house of his own. Then the world was at his feet.

1. What figure of speech is the bright sun continued to shine?

2. Why did Andrew insist on having an open air party?

3. What two hardships had Andrew gone through in life?

4. What is implied by the expression the "world was at his feet?"

5. What is implied by the courage to fail is very cheap?

6. What is meant by the expression the habitual doubting Thomas had no dissenting opinions to express?

7. What is meant by the expression "the reward of forbearance in the end is resounding success?

8. What does the expression "But Andrew did not despair mean?

\section{APPENDIX 2}

\section{Reading Comprehension Test 2}

The case of Mrs. Amanda is a classic example of the saying that when problems come they come not in singles but in battalions. Here is a woman who had lost her husband in a motor accident seven years after their wedding. Having to fend for their five children, she struggled to make ends meet by augmenting her income as a copy-typist with prettytrading. Things were at least fairly manageable, and the children were kept reasonable happy until things started to crumble. First, her neighbor, another woman, picked on her as a target. The quarrelsome woman found fault with everything Mrs. Amanda or her children did. Even when Mrs. Amanda decided not to answer her back, her silence was enough cause for provocation. Then one day, almost inevitable, the two women engaged in physical combat.

That caused the next problem. Mrs. Amanda had floored her neighbor in moment of extreme anger, and the other woman was rushed to the hospital by her husband. The doctor discovered that she had a cracked skull and that highly delicate surgery was necessary. The victim's husband would not take things lying down. He contacted the police; and Mrs. Amanda, already swimming in her tear for what had happened, found herself in a cell.

She was there for three days and was released only when her boss obtained a bill for her. On returning home she discovered that two of her children had caught measles and another had malaria. the eldest had been sent out of school for not having the prescribed books. Mrs. Amanda was utterly confused.

\section{Questions}

1. Give a suitable title to the passage

2. What is the topic sentence of the first paragraph?

3. What happened when Mrs. Amanda decided not to answer her neighbour back?

4. what is implied in the statement, then one day, almost inevitably the two women engaged in a physical combat

5. What is the topic sentence of the third paragraph?

6. In one sentence give the summary of the last paragraph

7. What are the words and phrases in the first paragraph, which points to the main idea in succeeding paragraph?

8. List four problems encountered by Mrs. Amanda

9. How did Mrs. Amanda feel after the fight?

10. What happened to Mrs. Amanda as a result of the husband's action? 